\title{
Essential Oil of Oregano and Savory; Chemical Composition and Antimicrobial Activity
}

\author{
Osman Emre Özkan¹, Kerim Güney², Mahmut Gür ${ }^{1}$, Esma Sena Pattabanoğlu², Erkan Babat², \\ Moustafa Milad Khalifa ${ }^{2}$
}

${ }^{1}$ Department of Forest Industrial Engineering, Faculty of Forestry, Kastamonu University, TURKEY.

${ }^{2}$ Department of Forest Engineering, Faculty of Forestry, Kastamonu University, TURKEY.

\begin{abstract}
The essential oils of oregano (Origanum vulgare ssp. hirtum) and savory (Satureja thymbra) plants were obtained through steam distillation method. The chemical compositions of their essential oils were analyzed via GC-MS technique. Furthermore, their antimicrobial activities were studied by using minimum inhibitory concentration (MIC) method. Their chemical composition was found as carvacrol (63.97\%), p-cymene $(12.63 \%)$ and linalool $(3.67 \%)$ in oregano essential oil as major compounds and also, as carvacrol $(42.7 \%)$, o-cymene $(17.98 \%)$, linalool $(9.65 \%)$, caryophyllene oxide $(5.25 \%)$ and $\gamma$-terpinene $(4.22 \%)$ in savory essential oil as major compounds. As a result, it can be said that that oregano and savory essential oil may be useful in the medicinal application and food industry as a preservative against harmful microorganisms.
\end{abstract}

Keywords: Oregano, Savory, Essential Oil, GC-MS, Antimicrobial Activity.

\section{INTRODUCTION}

The flora of Turkey has 23 species of Origanum (15 endemic) and 14 species of Satureja (4 endemic). ${ }^{1}$ One of the these species, Origanum vulgare subsp. birtum is a common East Mediterranean taxon, found mainly in the southern part of the Balkan region and in Turkey. ${ }^{2}$ Savory are aromatic plants used for production of essential oils (EOs). The savory found in the mountain of the Mediterranean region in Turkey. The oregano, thyme and savory leaves have been added to meat, fish and food products. ${ }^{4}$ They are known and used as species with a thymol/ carvacrol type odor in Turkey. ${ }^{1}$ The carvacrol and thymol type plants are used as flavoring and herbal tea, are taken especially to cure various illness. ${ }^{3-5,6}$ Origanum EO is used as a food additive and also as a fragrance component in cosmetic products. ${ }^{7,8}$ Food poisoning is problem in the World, even in well developed countries. So far many bacteria species has been reported as the causal agents of foodborne diseases. ${ }^{9}$ Essential oil of oregano and savory showed a good antioxidant capacity, ${ }^{9,10}$ antimicrobial activity against microorganisms ${ }^{1-3-9-10}$ and tyrosinase inhibition activity. ${ }^{5}$ In recent years, there have been important studies about the antimicrobial activity of essential oils of aromatic plants and their potential role in food preservation. ${ }^{11}$ The aim of this study is the determination of the chemical composition and antimicrobial activity of the oregano (Origanum vulgare subsp. birtum) and savory (Satureja thymbra) essential oils.

\section{MATERIALS AND METHODS}

\section{Plant Material}

The mature and healthy oregano (Origanum vulgare L. subsp. birtum) and savory (Satureja thymbra L.) dried leaves obtained from Özşen Lokman Hekim Company located in GIMAT-Ankara, TURKEY.
DOI: 10.5530/ijper.51.3s.13 Correspondence: Osman Emre Özkan, Department of Forest Industrial Engineering, Faculty of Forestry, Kastamonu University, TURKEY.

Phone no: +903662801719 , +905448722019 E-mail: oeozkan@kastamonu.edu.tr 


\section{Extraction of Essential Oil}

Essential oil was obtained by hydro distillation process using a Clevenger's type apparatus. After distillation process $\mathrm{EO}$ was separated and storage in refrigerator at $4{ }^{\circ} \mathrm{C}$.

\section{GC-MS Analyze}

For identification of essential oil components GC-MS QP2010 Ultra (Shimadzu) equipped with Rtx-5MS capillary column ( $30 \mathrm{~m} \cdot 0.25 \mathrm{~mm}$; coating thickness $0.25 \mu \mathrm{m}$ ) was used. Identification of the constituents was based on comparison of the retention times and on computer matching against Wiley Data library. GC-MS chromatograms were scanned in essential oil data library.

\section{Microorganism Strains}

In antimicrobial activity test Bacillus subtilis DSMZ 1971, Candida albicans DSMZ 1386, Enterococcus faecalis ATCC 29212, Enterobacter aerogenes ATCC 13048, Enterococcus durans, Enterococcus faecium, Escherichia coli ATCC 25922, Klebsiella pneumoniae, Listeria monocytogenes, Listeria innocua, Pseudomonas aeruginosa DSMZ 50071, Pseudomonas fluorescence P1, Salmonella enteritidis ATCC 13076, Salmonella infantis, Salmonella kentucky, Salmonella typhimurium SL 1344, Staphylococcus aureus ATCC 25923 and Staphylococcus epidermidis DSMZ 20044 was used. Most of the strains were ATCC, DSMZ and SL type standard strains. Other strains, which have no standard ID information were isolated from food samples and identified at the Department of Biology, Faculty of Science, and Ankara University.

\section{Antimicrobial Activity (MIC)}

A broth microdilution MIC test was applied with a slight modification. ${ }^{12}$ Two-fold dilutions of the oils were prepared ranging from $100 \mu \mathrm{g} / \mathrm{mL}$ to $0.195 \mu \mathrm{g} / \mathrm{mL}$ by using 96-well micro titration plate. The micro titration plates were incubated at $37{ }^{\circ} \mathrm{C}$ for $24 \mathrm{~h}$ for bacteria strains, where $27^{\circ} \mathrm{C}$ for $48 \mathrm{~h}$ for $\mathrm{C}$. albicans.

\section{RESULTS AND DISCUSSION}

The main components of the essential oil obtained from oregano and savory samples are given in Table 1. GC-MS analyses revealed that the main components of oregano EO was carvacrol (63.97\%), p-cymene (12.63\%) and linalool (3.67\%), $\alpha$-terpineol $(2.54 \%)$ and (-)-terpinen$4-\mathrm{ol}(2.24 \%)$; the main components of savory EO was carvacrol (42.7\%), o-cymene (17.98\%), linalool (9.65\%), caryophyllene oxide (5.25\%), $\gamma$-terpinene $(4.22 \%)$, caryophyllene (2.73\%) and (-)-borneol (2.24\%).

According to the MIC test results, oregano and savory essential oil showed a perfect antimicrobial activity against all test microorganisms with a MIC value of $<0.195 \mu \mathrm{g} / \mathrm{mL}$. The oregano and savory essential oil showed very strong antimicrobial activity against $B$. subtilis, C. albicans, E. faecalis, E. aerogenes, E. durans, E. faecium, E. coli, K. pneumoniae, L. monocytogenes, L. innocua, P. aeruginosa, P. fluorescence, S. infantis, S. kentucky, S. typhimurium, S. aureus and S. epidermidis with a MIC value of $<0.195$ $\mu \mathrm{g} / \mathrm{mL}$ for all microorganisms.

As the current literature is concerned there are several studies for the antimicrobial activity of oregano and savory against several microorganisms. The oregano and savory essential oil showed very strong antimicrobial activity against 19 different test microorganisms. Previous studies shows that the essential oils obtained from plants of Origanum and Satureja species have been found to have significant antimicrobial activities. ${ }^{1-3}$ These properties depend greatly on their chemical compositions such as carvacrol, ${ }^{13}$ linalool, ${ }^{14} \alpha$-terpineo ${ }^{14}$ and $\gamma$-terpinene. ${ }^{15}$

\section{CONCLUSION}

\begin{tabular}{|c|c|c|c|c|c|}
\hline Essential Oil & Components & $\begin{array}{c}\text { Relative } \\
\text { Area \% }\end{array}$ & $\begin{array}{l}\text { Essential } \\
\text { Oil }\end{array}$ & Components & $\begin{array}{c}\text { Relative Area } \\
\%\end{array}$ \\
\hline \multirow{7}{*}{ Oregano } & carvacrol & 63.97 & \multirow{7}{*}{ Savory } & carvacrol & 42.7 \\
\hline & p-cymene & 12.63 & & o-cymene & 17.98 \\
\hline & linalool & 3.67 & & linalool & 9.65 \\
\hline & a-terpineol & 2.54 & & caryophyllene oxide & 5.25 \\
\hline & (-)-terpinen-4-ol & 2.24 & & $\mathrm{y}$-terpinene & 4.22 \\
\hline & & & & caryophyllene & 2.73 \\
\hline & & & & (-)-borneol & 2.24 \\
\hline
\end{tabular}


Finally, it can be suggested that the essential oils of oregano and savory have perfect antimicrobial activities against different microorganisms. In view of their activity, these essential oils may find industrial applications as natural conservative and agents in the pharmaceutical and food industries.

\section{ACKNOWLEDGEMENT}

The authors are thankful to Kastamonu University for providing research facility.

\section{CONFLICT OF INTEREST}

None

\section{ABBREVIATION USED}

GC-MS: Gas chromatography-mass spectrometry; EO: Essential Oil; GIMAT: Association of Food and Consumer Goods Ankara; DSMZ: German Collection of Microorganisms and Cell Cultures; ATCC: American Type Culture Collection; ID: Identity; MIC: Minumum Inhibitory Concentration.

\section{REFERENCES}

1. Baydar H, Sağdiç $O$, Özkan G, Karadoğan $T$. Antibacterial activity and composition of essential oils from Origanum, Thymbra and Satureja species with commercial importance in Turkey. Food Control. 2004;15(3):169-72.

2. Vokou D, Kokkini S, Bessiere J-M. Geographic variation of Greek oregano (Origanum vulgare ssp. hirtum) essential oils. Biochem Syst Ecol. 1993;21(2):287-95.

3. Sarac N, Ugur A. Antimicrobial activities of the essential oils of Origanum onites L., Origanum vulgare L. subspecies hirtum (Link) letswaart, Satureja thymbra L., and Thymus cilicicus Boiss. \& Bal. growing wild in Turkey. J Med Food. 2008;11(3):568-73.

4. Sagdıç O, Özcan M. Antibacterial activity of Turkish spice hydrosols. Food Control. 2003;14(3):141-3.

5. Rao GV, Mukhopadhyay T, Annamalai T, Radhakrishnan N, Sahoo M. Chemical constituents and biological studies of Origanum vulgare Linn. Pharmacognosy Res. 2011;3(2):143.

6. Vattem D, Lester C, DeLeon R, Jamison B, Maitin V. Dietary supplementation with two Lamiaceae herbs-(oregano and sage) modulates innate immunity parameters in Lumbric us terrestris. Pharmacognosy Res. 2013;5(1):1.

7. Prieto JM, lacopini $\mathrm{P}$, Cioni $\mathrm{P}$, Chericoni $\mathrm{S}$. In vitro activity of the essential oils of Origanum vulgare, Satureja montana and their main constituents in peroxynitrite-induced oxidative processes. Food Chem. 2007;104(3):889-95.

8. Suzuki ÉY, Soldati PP. Essential oil from Origanum vulgare Linnaeus: an alternative against microorganisms responsible for bad perspiration odor. $J$ Young Pharm. 2015;7(1):12.

9. Şahin F, Güllüce M, Daferera D, Sökmen A, Sökmen M, Polissiou M, et al. Biological activities of the essential oils and methanol extract of Origanum vulgare ssp. vulgare in the Eastern Anatolia region of Turkey. Food Control. 2004;15(7):549-57.

10. Sarikurkcu C, Zengin G, Oskay M, Uysal S, Ceylan R, Aktumsek A. Composition, antioxidant, antimicrobial and enzyme inhibition activities of two Origanum vulgare subspecies (subsp. vulgare and subsp. hirtum) essential oils. Ind Crops Prod. 2015;70:178-84.

11. Ghalfi H, Benkerroum N, Doguiet D, Bensaid M, Thonart P. Effectiveness of cell-adsorbed bacteriocin produced by Lactobacillus curvatus CWBI-B28 and selected essential oils to control Listeria monocytogenes in pork meat during cold storage. Lett Appl Microbiol. 2007;44(3):268-73.

12. Balouiri M, Sadiki M, Ibnsouda SK. Methods for in vitro evaluating antimicrobial activity: A review. J Pharm Anal. 2016;6(2):71-9.

13. Chorianopoulos N, Kalpoutzakis E, Aligiannis N, Mitaku S, Nychas G-J, Haroutounian SA. Essential oils of Satureja, Origanum, and Thymus species: chemical composition and antibacterial activities against foodborne pathogens. J Agric Food Chem. 2004;52(26):8261-7.

14. Carson C, Riley T. Antimicrobial activity of the major components of the essential oil of Melaleuca alternifolia. J Appl Bacteriol. 1995;78(3):264-9.

15. Mahboubi M, Kazempour N. Chemical composition and antimicrobial activity of Satureja hortensis and Trachyspermum copticum essential oil. Iran J Microbiol. 2011;3(4):194-200.

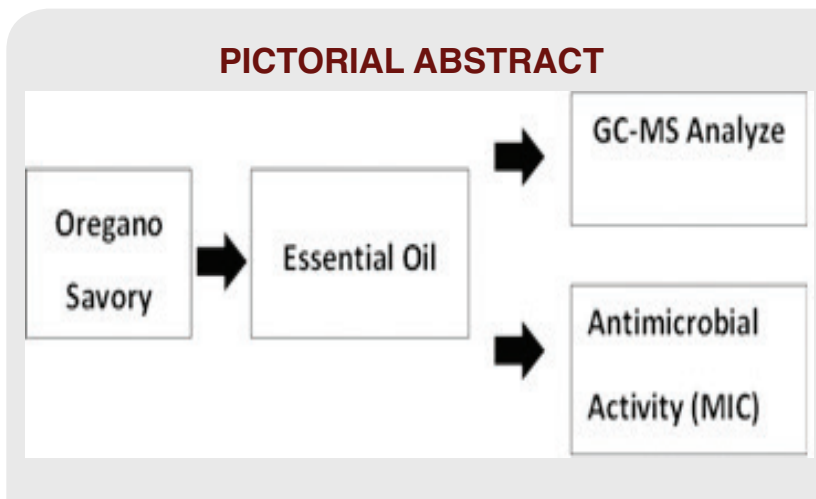

\section{SUMMARY}

- Antimicrobial activities of the Oregano and Savory essential oils were investigated by using MIC test by against 18 different species microorganisms.

- Furthermore, the contents of the essential oils were determined with GC-MS.

- As a result, it can be said that the essential oils of Oregano and Savory can be used as antimicrobial agent.

\section{ABOUT AUTHORS}

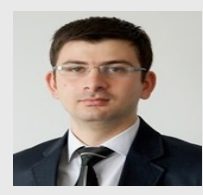

Osman Emre Özkan is working as a research assistant in Forest Industry Engineering Department, Faculty of Forestry in Kastamonu University, TURKEY. Research interests include non-wood forest product and its biological activity. 


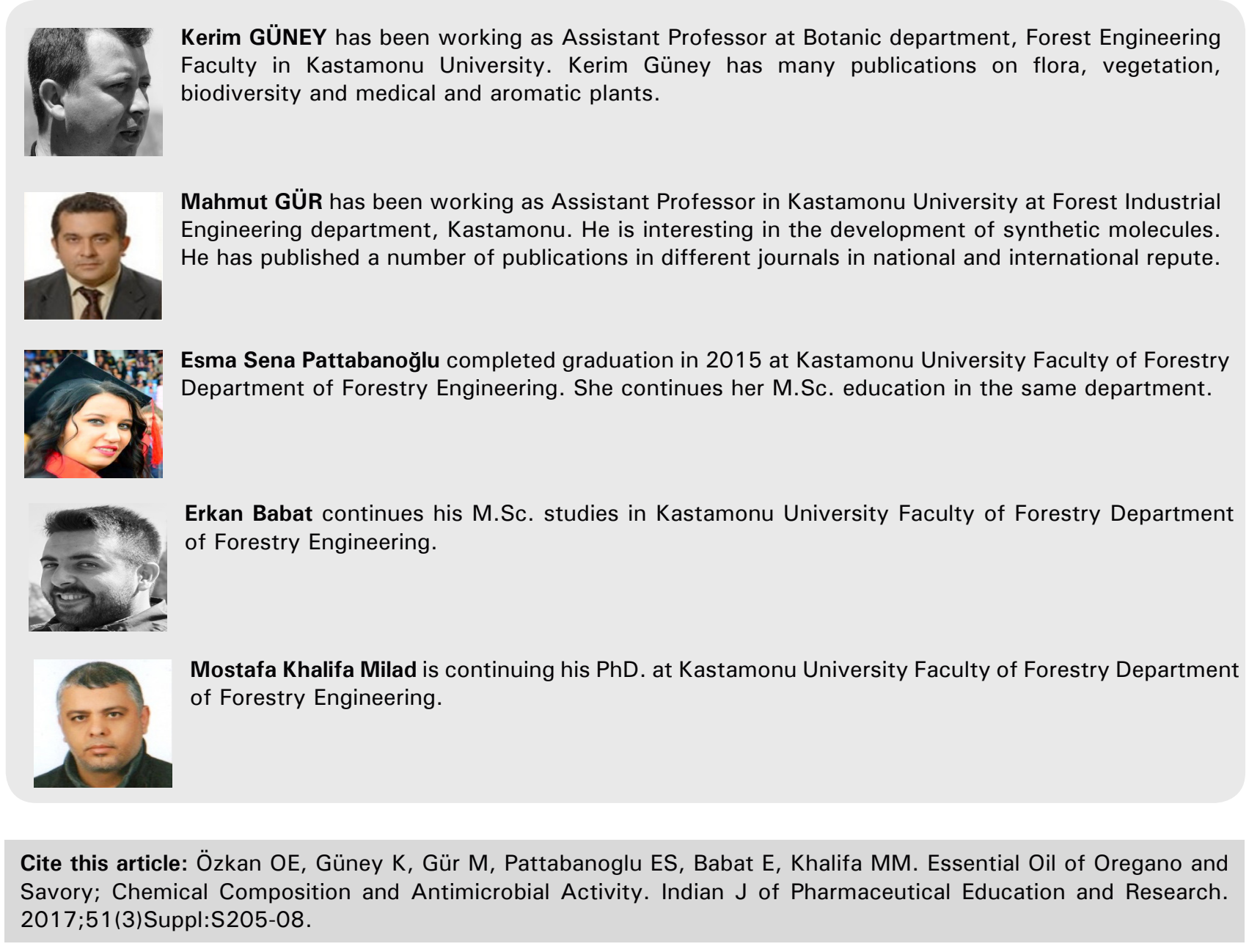

